\title{
CHARACTERISTICS AND ASSESSMENT OF SELECTED WATERFALLS FORMED IN DIFFERENT GEOLOGICAL BASEMENTS IN THAILAND
}

\author{
Vimoltip SINGTUEN* \\ Khon Kaen University, Faculty of Technology, Department of Geotechnology, Khon Kaen, Thailand, e-mail: vimoltipst@gmail.com \\ Burapha PHAJUY \\ Chiang Mai University, Faculty of Science, Department of Geological Sciences, Chiang Mai, Thailand, e-mail: buraphaphj3@gmail.com
}

Elżbieta GAŁKA

AGH University of Science and Technology, Faculty of Geology, Geophysics and Environmental Protection, Department of General Geology and Geotourism, 30-059, Kraków, Poland, e-mail: egalka@agh.edu.pl

\begin{abstract}
Citation: Singtuen, V., Phajuy, B., \& Gałka, E. (2021). CHARACTERISTICS AND ASSESSMENT OF SELECTED WATERFALLS FORMED IN DIFFERENT GEOLOGICAL BASEMENTS IN THAILAND. GeoJournal of Tourism and Geosites, 37(3), 880-887. https://doi.org/10.30892/gtg.37319-721
\end{abstract}

\begin{abstract}
Thailand is under the influence of the complicated tectonic settings, resulting in various geomorphological features, especially waterfalls. There has been no insightful research conducted to describe the relationship between the types of waterfalls and the lithology of basements. Thus, this work aims to classify representative waterfalls and describe their lithology, origin, and characteristics. The twelve selected waterfalls are distributed in ten provinces with different basements. Field investigations (lithology, structure, and geomorphology) and geoinformatics analysis were integrated and co-interpreted with geological interpretations, characteristics, classification, and assessment. High-grade metamorphic rocks associated with granitoids demonstrate fan-type waterfalls with high slopes, and limestone presents multi-tiered waterfalls with vividly coloured pools, while sandstone in the Khorat Plateau exhibits three types of waterfalls including cascade, plunge, and punchbowl. National park authorities manage all the studied waterfalls, so these areas have outstanding natural and tourism values, while education and international also present good scores.
\end{abstract}

Key words: geomorphology, geology, geotourism, fan-type waterfall, cascade, landform

\section{INTRODUCTION}

Waterfalls often form in the headwaters, where lakes in valleys flow into steep mountains (Carreck, 1982). Based on their locations in the landscape, many waterfalls occur over bedrock fed by low-contributing terrain. Thus, the waterfalls may be ephemeral and flow only during rainfalls. Downstream rivers have more consistent waterfalls with various scales of depth, width, and length. When the river flows over resistant bedrock, erosion is slow and dominated by the impact of water-borne sediment on the bedrock. In contrast, downstream erosion is more rapid (Carreck, 1982) as the watercourse increases its velocity at the edge of the waterfall, it may uproot material from the riverbed if the bed is fractured or otherwise more erodible. Hydraulic jets and hydraulic jumps at the toe of a fall can generate large forces that erode the bed significantly when amplified by water-borne sediment (Pasternack et al., 2006, 2007). Horseshoe-shaped falls focus erosion on a central point, enhancing riverbed change below the waterfalls (Pasternack et al., 2006, 2007). A river sometimes flows over a giant step in the rocks that a fault line may have formed (Carreck, 1982). The classification divided waterfalls into ten types (National Geographic, 2018; Goudie, 2019), which consist of (1) a block waterfall with a comprehensive stream, (2) a cascade descending over a series of rock steps, (3) a powerful and dangerous cataract, (4) a chute with stream passage that is very narrow, (5) a waterfall with a fan-like shape, (6) a horsetail waterfall contacting with hard rock, (7) a multi-step waterfall connecting waterfalls with plunge pool, (8) a plunge waterfall lose contact with hard rock, (9) a punchbowl waterfall with vast pool at the base, and (10) a segmented waterfall that flows in separate and distinct streams. The size of a waterfall is considered by the height of the most significant vertical fall, the site's width, and the combined height of all falls at a site (Matthes, 1922; Plumb, 1993; Mabin, 2000).

Thailand has various types of landforms, all of which are the inspiration for this work. The northern region comprises the Thai highlands and consists of mountainous areas as well as intermountain basins, with Doi Inthanon being the highest point in the western part of Chiang Mai Province. The well-known Khorat Plateau in the northeast is bordered to the east by the Mekong River. Meanwhile, central Thailand is dominated by floodplains, with some small hills crossed by many rivers that discharge their sediments into the Gulf of Thailand. The southern region is a narrow strip of land between the Indian Ocean (Andaman Sea) to the west and the Pacific Ocean (Gulf of Thailand) to the east (Figure 1). The waterfalls are some of the famous landforms that are the destination for tourists, both Thais and foreigners. Therefore, this work describes and compares the waterfall characteristics of waterfalls in the different basements, including intrusive, volcanic, clastic sedimentary, chemical sedimentary, and metamorphic rocks.

\footnotetext{
* Corresponding author
} 


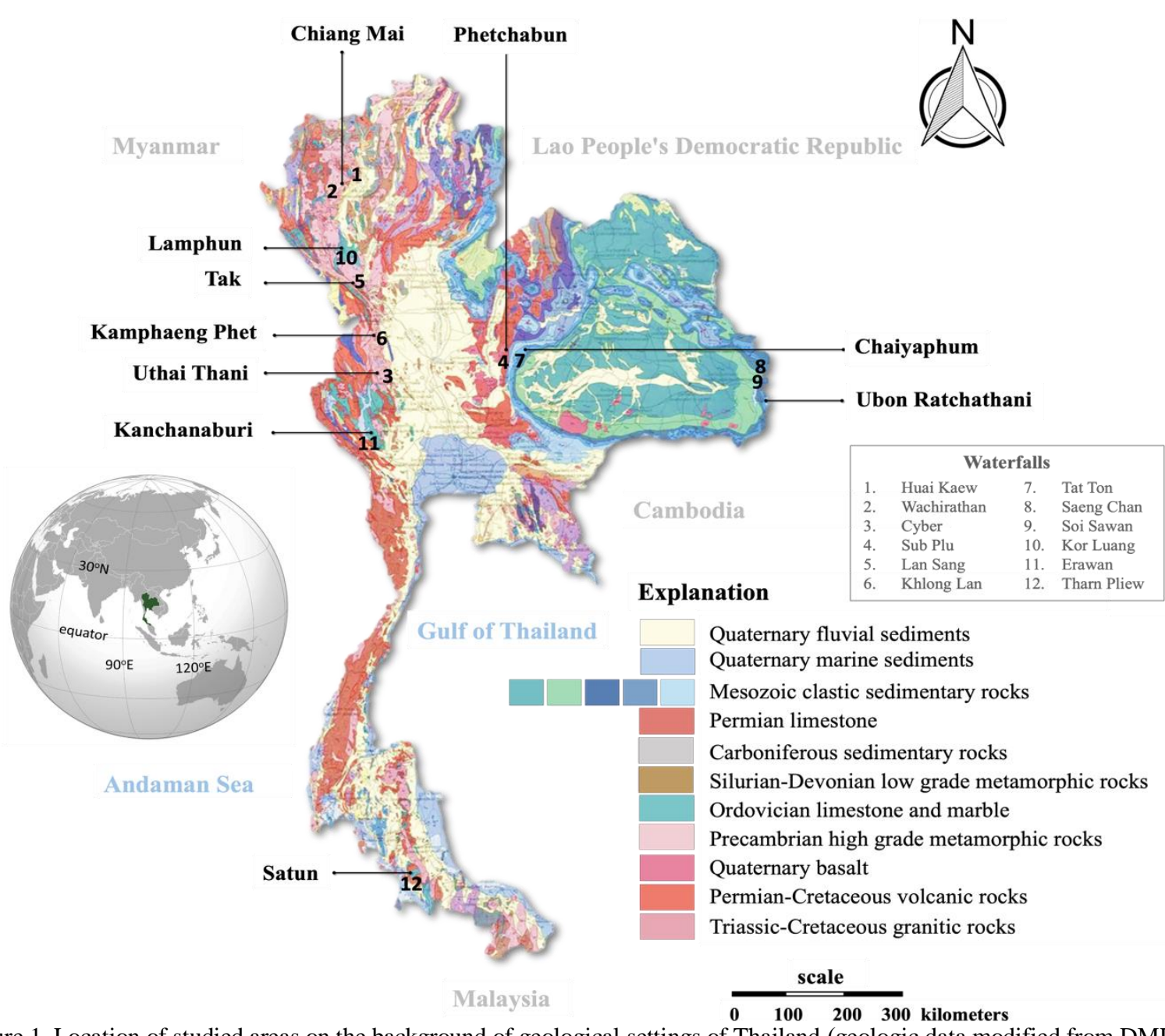

Figure 1. Location of studied areas on the background of geological settings of Thailand (geologic data modified from DMR, 1999)

Thailand is generally accepted to be composed of at least two ancient terranes as the Shan-Thai or Sibumasu and Indochina, which collided as tectonic plate landmasses during the Triassic period (Bunopas, 1981; Metcalfe, 2011; Metcalfe, 2013; Sone and Metcalfe, 2008; Ueno and Hisada, 2001). The Indochina terrain was derived from the Gondwana Supercontinent that existed in the Devonian era, while the Shan-Thai originated during the Late Carboniferous (Metcalfe, 2011; Metcalfe, 2013; Ueno and Hisada, 2001; Sone et al., 2012). Regarding the last event, this region is affected by the collision of Indian-Eurasian plates in the Cretaceous-recent. The Palaeo-Tethys Ocean separated these two terrains during the middle-upper Palaeozoic era before the Late Triassic-Early Jurassic convergence (Bunopas, 1981; Sone and Metcalfe, 2008). Therefore, many kinds of rocks are distributed in the region, including intrusive, volcanic, clastic sedimentary, chemical sedimentary, and metamorphic rocks (Figure 1). High-grade metamorphic and granitic rocks formed as high and complex mountain ranges in the West, northern and western parts of Thailand. Silurian-Devonian low-grade metamorphic rocks are presented as high lateral mountains in northern and small mountains in central Thailand. Granitoids of Triassic to Cretaceous intruded as batholiths and present as a mountain range in the northern and southern parts, while in Thailand's central and Loei Province occur as stock and present as a single mountain. Volcanic and associated rocks are distributed throughout this region, especially in the north, from Permian to Cretaceous. Cenozoic basalts, which still show volcanic features, generally erupted in the lower terrane of north-central-east Thailand and south of the Khorat Plateau. Ordovician and Permian limestone are distributed as high mountains and generally show karst landforms, excluding the Khorat Plateau. Mesozoic sedimentary rocks are mainly distributed in the Khorat Plateau (NE Thailand) and small areas in the northern part of Thailand. Geotectonic processes in Thailand are currently influenced by mainland Southeast Asia comprising many georesources in the form of a multitude of geomorphological features. Cenozoic strike-slip faults affect many scales of basins and fault escarpments, presenting cliffs and waterfalls (Bait et al., 1997; Fenton et al., 1997; Kosuwan et al., 1998; Singtuen and Won-In, 2018a).

\section{MATERIALS AND METHODS}

This study focused on outstanding waterfalls considering both geology and tourism in Thailand. General geotourism study methods were used, including inventory, field observation, characterisation, classification geoinformatics analysis and results in interpretation of twelve waterfalls: Wachirathan, Lan Sang, Khlong Lan, Huai Kaew, Cyber, Sub Plu, Tat Ton, Saeng Chan, Soi Sawan, Kor Luang, Erawan, and Tharn Pliew. These waterfalls are distributed in ten provinces: Chiang Mai, Tak, Kamphaeng Phet, Uthai Thani, Phetchabun, Chaiyaphum, Ubon Ratchathani Lamphun, Kanchanaburi, and Satun (Table 1). Materials for analysis consisted of topographic maps, geological maps, satellite imagery, and 
previous geologic research. Accordingly, criteria such as occurrence, rarity, integrity, and representativeness of geological features must be taken into consideration for the geosite identification process (Đurović and Đurović, 2010, Pralong, 2005, Nazaruddin, 2015). Waterfalls were inventoried and mapped based on their significant geotourism values. In addition, this work also characterised and classified selected waterfalls in different rock basement types and interpreted their occurrence.

Thus, field investigations and geomorphological analysis by Google Earth Pro 7.3.3.7786 (64bit) with NVIDIA Graphics Driver (00027.00020.00100.08681) were integrated to determine the shape, elevation, slope, and type. Furthermore, this work assessed all waterfalls regarding both qualitative and quantitative international, natural, cultural, educational, and economic geotourism significance.

Table 1. Location and basement rocks of the selected waterfalls

\begin{tabular}{|c|c|c|c|c|}
\hline Waterfall & Province & Location & Rock Type & Rock Name \\
\hline Huai Kaew & Chiang Mai & $18.81187 \mathrm{~N} 98.94451 \mathrm{E}$ & \multirow{6}{*}{$\begin{array}{l}\text { Igneous and } \\
\text { Metamorphic } \\
\text { Rock }\end{array}$} & \multirow{2}{*}{ Triassic Granite } \\
\hline Cyber & Uthai Thani & $15.30414 \mathrm{~N} 99.42243 \mathrm{E}$ & & \\
\hline Sub Plu & Phetchabun & $15.85101 \mathrm{~N} 101.28203 \mathrm{E}$ & & Cenozoic Basalt \\
\hline Wachirathan & Chiang Mai & $18.54242 \mathrm{~N} 98.59817 \mathrm{E}$ & & \multirow{3}{*}{$\begin{array}{l}\text { Precambrian } \\
\text { Gneiss }\end{array}$} \\
\hline Lan Sang & Tak & $16.77746 \mathrm{~N} 99.00300 \mathrm{E}$ & & \\
\hline Khlong Lan & Kamphaeng Phet & $16.13092 \mathrm{~N} 99.27680 \mathrm{E}$ & & \\
\hline Tat Ton & Chaiyaphum & $15.98210 \mathrm{~N} 102.03892 \mathrm{E}$ & \multirow{6}{*}{$\begin{array}{l}\text { Sedimentary } \\
\text { Rock }\end{array}$} & \multirow{3}{*}{$\begin{array}{l}\text { Mesozoic } \\
\text { Sandstone }\end{array}$} \\
\hline Saeng Chan & Ubon & $15.51613 \mathrm{~N} 105.58967 \mathrm{E}$ & & \\
\hline Soi Sawan & Ratchathani & $15.45975 \mathrm{~N} 105.57903 \mathrm{E}$ & & \\
\hline Kor Luang & Lamphun & $17.58352 \mathrm{~N} 98.81750 \mathrm{E}$ & & \multirow{3}{*}{$\begin{array}{l}\text { Permian } \\
\text { Limestone }\end{array}$} \\
\hline Erawan & Kanchanaburi & $14.36880 \mathrm{~N} 99.14394 \mathrm{E}$ & & \\
\hline Tharn Pliew & Satun & $7.13354 \mathrm{~N} 99.83841 \mathrm{E}$ & & \\
\hline
\end{tabular}

\section{Waterfall's Characteristics and Classification}

\section{Igneous and Metamorphic basement}

All igneous and metamorphic bases always produce a fan-type waterfall, in which the water circulates horizontally as it descends and remains in contact with the bedrock (Figure 2).
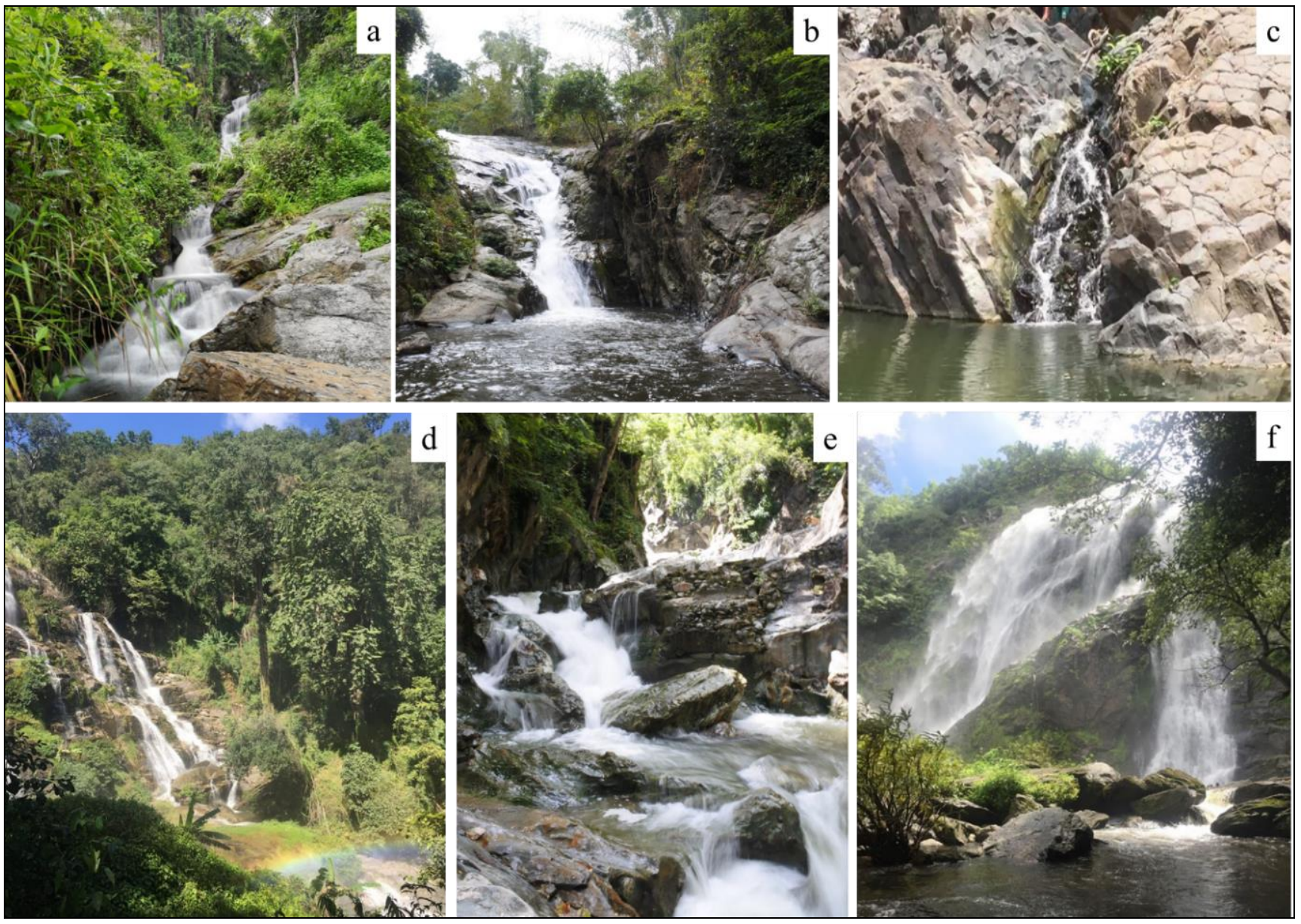

Figure 2. The morphology of waterfalls in igneous and metamorphic basements

(a) Huai Kaew, (b) Cyber, (c) Sub Plu, (d) Wachirathan, (e) Lan Sang, and (f) Khlong Lan

Huai Kaew waterfall is a part of Suthep-Pui National Park in Chiang Mai (Figure 2a), which was truncated by the Chiang Mai Low Angle Normal Fault (CMLANF) in the Eocene-Oligocene period (Morley, 2009a, 2009b; Macdonald et al., 2010). This complicated geological area consists of stress granites with the relicts of high-grade metamorphic rocks (gneiss, marble, and calc-silicate rock), and pegmatites/aplite that intruded by the Triassic S-type granitic rocks (Beckinsale et al., 1979; Beckinsale, 1981; Hutchison, 1983) forming a high mountain in the western Chiang Mai Basin. 
Huai Kaew waterfall displays the Huai Kaew stream flows from west to east for merging with Mae Ping River in the basin centre. This waterfall is small (height about 10 meters) with a perennial stream, presenting Chiang Mai's beautiful landform and stunning landscape. Cyber waterfall in the western part of Uthai Thani Province is a peaceful natural area and has many waterfalls in a perennial stream such as Loi Choi and Hin Lat. This area presents a Triassic granite - granodiorite basement that resulted from Srisawat fault segment movement (Figure 2b). The river flows upstream from the high mountain of Huai Kha Khaeng Wildlife Sanctuary in the western flank to the eastern. It is protected and conserved by the Cyber Forest Preservation Unit. Sub Phlu waterfall flows through columnar basalts with an intermittent stream of the Phetchabun National Geopark. These Cenozoic basalts have transitional composition between Tholeiite and Calc-alkaline Series, which occurred in a continental rifting process similar to Wichian Buri basalt (Limtrakul et al., 2013; Sriwichai et al., 2018). After this basalt eruption, the area was controlled by the Phetchabun fault segments, making a columnar basalt waterfall tilted with many small steps developed by streamflow (Figure 2c). Wachirathan is a part of Doi Inthanon National Park (the highest mountain peak of Thailand), Chiang Mai Province. This waterfall demonstrates that the Klang River flows from the Doi Inthanon Mountain range to the south-eastern flank (Figure 2d). Doi Inthanon is the western part of the CMLANF and is covered by the PreCambrian-like metamorphic rocks (Doi Inthanon metamorphic core complex), comprising orthogneisses, paragneisses, mica schists, calc-silicates, and pegmatites (e.g., Baum et al., 1981; MacDonald et al., 1993). Wachirathan is one of the largest waterfalls in a perennial stream, presenting only one tier with 80 meters in height. Thus, this waterfall displays beautiful scenery throughout the year. Lan Sang is located in Lan Sang National Park, western Tak Province, and is affected by the striking Mae Ping fault 66.2 $\pm 1.6 \mathrm{Ma}$ in area from the northwest to southeast (Palin et al., 2013). It is covered by Precambrian gneisses, Tertiary augen gneisses, and other metamorphic rocks (DMR, 1999; Österle et al., 2019). These rocks should have undertaken high-grade metamorphism belonging to greenschist facies and amphibolite facies and started from granitic and sedimentary protoliths prior to regional metamorphism in Late Eocene-Early Miocene magmatism (Österle et al., 2019). This waterfall is a part of the Huai Lan Sang stream (perennial stream) that flows from the Thanon Thong Chai Range (Figure 2e), demonstrating four tiers with approximately 40 meters in height. Khlong Lan is one of two stunning waterfalls in the Khlong Lan National Park, which is situated on Khun Khlong Lan Mountain in the Dawna Mountain range, which comprised of high-grade metamorphic rocks (gneisses, calc-silicates, and schists) associated with granitic rocks similar to the Lan Sang area. This area lies in the districts of Khlong Lan and Mueang Kamphaeng Phet, Kamphaeng Phet Province, located in the west of Thailand. Khlong Lan waterfall is a nine-tier waterfall with a perennial stream (Figure 2f).

\section{Sandstone basement}

Almost all sandstone waterfalls in Thailand occur in the Khorat Plateau, NE Thailand.

The Tat Ton cascade is on a perennial stream, presenting only one tier that is 7 meters in height and 30 meters in width at Tat Ton National Park, Chaiyaphum Province. The Tat Ton is built of the Phra Wihan Formation, Khorat Group. This formation comprises well-sorted, rounded, fine- to coarse-grained, pale-yellow sandstones, thin-bedded siltstones, mudstones, and conglomerates. Thick sandstone beds, occurring as high cliffs, were deposited in a braided stream environment, whereas thinner sandstone beds were deposited in meandering rivers (Meesook, 2000).

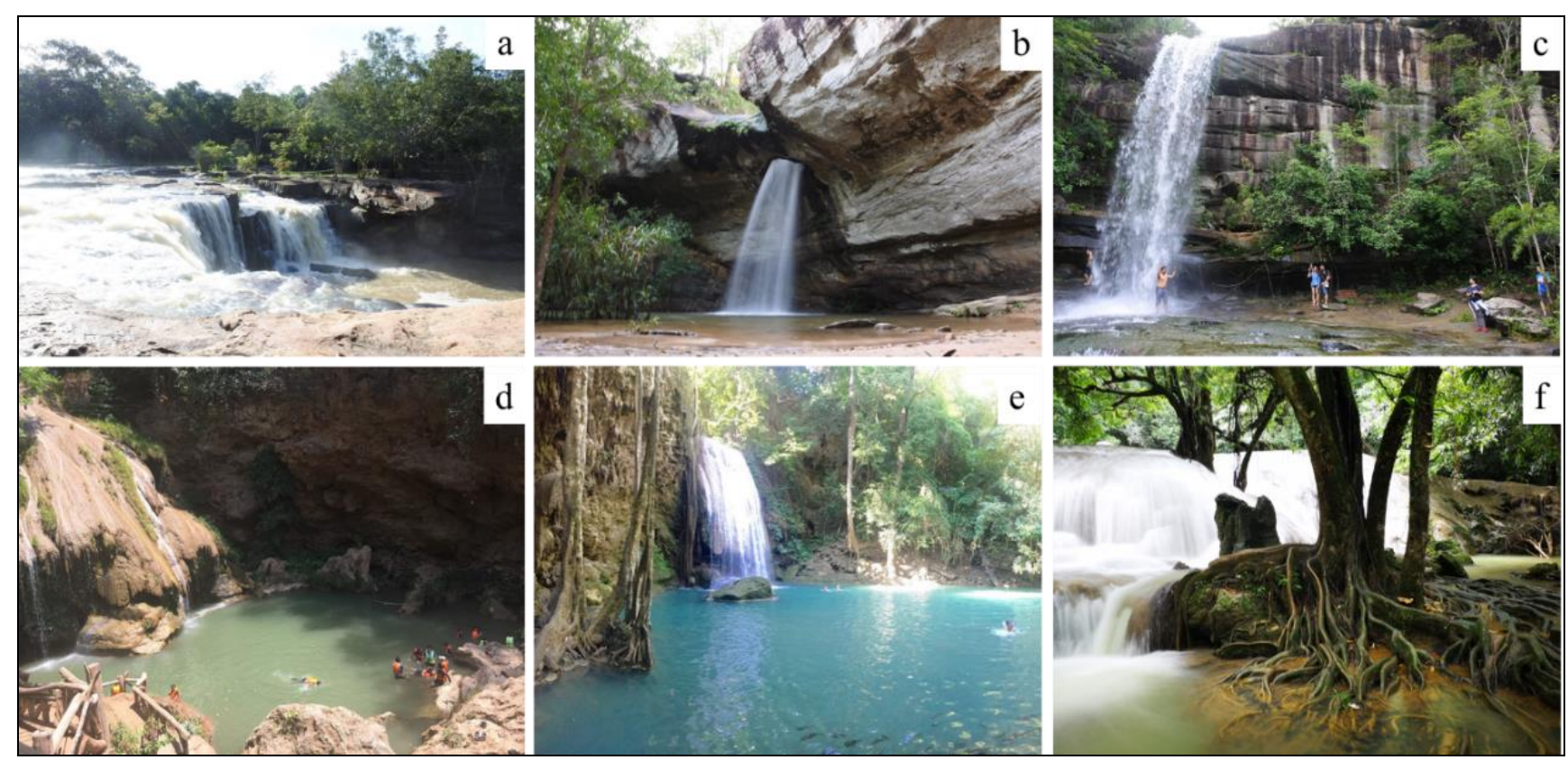

Figure 3. The morphology of waterfalls in sedimentary and limestone basements

(a) Tat Ton, (b) Saeng Chan, (c) Soi Sawan, (d) Kor Luang, (e) Erawan, and (f) Tharn Pliew

The steep scarp is formed of very resistant sandstones. Meanwhile, the less resistant rocks are siltstones and mudstones (Figure 3a). This type of waterfall is rare in Thailand. However, the Tat Ton waterfall is representative of the north-eastern part of the country (Singtuen and Won-In, 2018). Saeng Chan (two-tier waterfall that is 7 meters in height) and Soi Sawan 
waterfall (20 meters in height) are located in Pha Chan-Sam Phan Bok National Geopark, Ubon Ratchathani Province, which is in the eastern most edge of the Khorat Plateau. These cascades are formed on perennial streams and dominated by the Phu Phan Formation, Khorat Group, which consists of medium to coarse-grained light grey sandstones. Some sandstones grade into thick beds of a conglomerate with large planar and trough cross-bedding. Pebbles consist of white quartz, grey and green volcanic rocks, and various colours of cherts. Detrital grains are well rounded but poorly sorted. In some areas, lenses of dark grey shales are found interbedded. This rock formation was deposited in braided streams and meandering rivers conditions in hot-humid to the semi-arid environment (Meesook, 2000). The Saeng Chan waterfall is a unique feature that flows through a mountain tunnel to a pool below (Figure 3b). It is classified as the Punchbowl type, presenting water that descends in a constricted form, and then it spreads out into a broader pool. In addition, Soi Sawan waterfall is a large perennial plunge-type waterfall originating from 2 main creeks before merging with the Mekong River (Figure 3c).

\section{Limestone basement}

Both Ordovician and Permian Limestone mainly form the multi-tiered, foliage-framed waterfalls, presenting with vividly coloured streams, tufa, and emerald green small pools. The tufa is formed on the rock surfaces when $\mathrm{CaCO}_{3}+\left(\mathrm{H}_{2} \mathrm{O}\right.$ $\left.+\mathrm{CO}_{2}\right)$ dissolves $\mathrm{Ca}\left(\mathrm{HCO}_{3}\right)_{2}$ from the lime-rich waters, leaving calcite $\left(\mathrm{CaCO}_{3}\right)$ to crystallize and $\mathrm{H}_{2} \mathrm{O}(\mathrm{l})+\mathrm{CO}_{2}(\mathrm{~g})$ evaporate. The tufa-coated rock surface with flowing water is not slippery. Kor Luang is located in Mae Ping National Park, Lamphun Province, which displays a seven-tier perennial stream that is 20 meters in height. This waterfall is one of the well-known waterfalls in Thailand and is very famous for tourists in all seasons. Kor Luang waterfall is covered by Ordovician limestone, which consists of greyish argillaceous and dolomitic limestone associated with marble and some fossils (Figure 3d). Meanwhile, the Erawan waterfall in Kanchanaburi is covered by Permian limestone composed of massive and dolomitic limestone with chert nodules and numerous fossils (Figure 3e). This waterfall is located on a perennial stream in the Tenasserim Hills range, western Thailand, with 7 tiers and emerald green ponds. Moreover, Tharn Pliew in Satun UNESCO Global Geopark (Figure 3f) is a mountainous limestone area in the north with a five-meter-high waterfall and smaller waterfalls down below. The water source is a perennial stream from cavities or caves in the dark grey Ordovician limestone (similar as Kor Luang) mountains with calcium carbonate dissolution. Water from the main waterfall is diverged into many creeks, falling onto many levels of terraces which finally converge into a single stream.

\section{Waterfalls Basic Parameters}

Since there are many kinds of rocks in Thailand, there are many features and characteristics of waterfalls. This study presents waterfalls in different basement rocks including (1) igneous and metamorphic rocks, (2) clastic sedimentary rocks, and (3) limestone. These waterfalls are classified as fan, punchbowl, cascade, plunge, and multi-tiered. Table 2 presents the critical numeric data for the selected waterfalls comprising the upstream and downstream elevation, length of tourism zone, and maximal and average slopes A fan-type waterfall formed from faultcontrolled igneous and metamorphic rocks always has a high slope value, presenting a steep slope

(Figure 4) and stunning stream flow phenomena.

Excluding columnar waterfall depends on the main structural geology and the size of the lava flow. When a stream flows through limestone basements, calcite and other carbonate minerals are dissolved, with the rocks forming the karst topography or high slope waterfall by weathering and erosion processes. Kor Luang, Erawan, and Tharn Pliew waterfalls display a similar trend of slopes, 4.6-5.1\% in max slope and 2.1-3.2\% in average slope. In addition, clastic sedimentary rocks show different trends of the slope, both steep and gentle. Cascade (gentle slope) formally occurs in clastic sedimentary basements with different bedding resistance and non-resistance rocks (Figure 4). There are noteworthy features like Soi Sawan Waterfall, which presents a steep slope with streamflow in the escarpment slope.

\section{Waterfalls Assessment for Geotourism Development}

Qualitative assessment (Table 3) focuses on the international, natural, cultural, educational, and economic geotourism implications. Meanwhile, the quantitative assessment evaluates all those values in preliminary numerical criteria that consist of zero (0) to five (5) scoring, denoting none, very poor, poor, fair, good, and very good, respectively. All the selected waterfalls are located in national parks that manage and protect physical and natural features by national legislation (Singtuen and WonIn, 2018a; Singtuen and Won-In, 2018b; Singtuen and Won-In, 2018c; Singtuen and Won-In, 2019). Thus, these waterfalls automatically have high natural values with biotic (plants and animals) and abiotic (landforms and landscapes) components. The selected waterfalls also have aesthetic and tourism values by default because the national park organisations manage and develop them for serving visitors. International value relates to the number of geological research promotions via peer-reviewed journals or international-specific conferences. There are different numbers and ranks of their international publications (Singtuen and Won-In, 2018a; Singtuen and Won-In, 2018b; Singtuen and Won-In, 2018c; Singtuen and Won-In, 2019). 
Table 3. Quantitative assessment of selected waterfalls in Thailand

\begin{tabular}{|c|c|c|c|c|c|c|}
\hline \multirow[b]{2}{*}{ Rock } & \multirow[b]{2}{*}{ Waterfall } & \multicolumn{5}{|c|}{ Values } \\
\hline & & $\begin{array}{c}\text { Inter- } \\
\text { national }\end{array}$ & $\begin{array}{l}\text { Na- } \\
\text { ture }\end{array}$ & $\begin{array}{l}\text { Cul- } \\
\text { ture }\end{array}$ & $\begin{array}{l}\text { Edu- } \\
\text { cation }\end{array}$ & $\begin{array}{l}\text { Eco- } \\
\text { nomy }\end{array}$ \\
\hline \multirow{3}{*}{$\begin{array}{l}\text { Precam- } \\
\text { brian } \\
\text { Gneiss }\end{array}$} & Wachirathan & \begin{tabular}{|l|}
4 \\
\end{tabular} & 5 & 3 & 2 & 5 \\
\hline & Lan Sang & 5 & 5 & 1 & 4 & 2 \\
\hline & Khlong Lan & 2 & 5 & 2 & 2 & 4 \\
\hline \multirow{2}{*}{$\begin{array}{l}\text { Triassic } \\
\text { Granite }\end{array}$} & Cyber & 3 & 5 & 1 & 2 & 2 \\
\hline & Huai Kaew & 4 & 5 & 5 & 2 & 5 \\
\hline $\begin{array}{c}\text { Cenozoic } \\
\text { Basalt }\end{array}$ & Sub Plu & 4 & 5 & 1 & 2 & 1 \\
\hline \multirow{3}{*}{$\begin{array}{l}\text { Mesozoic } \\
\text { Sandstone }\end{array}$} & Tad Ton & 4 & 5 & 1 & 4 & 1 \\
\hline & Saeng Chan & 3 & 5 & 1 & 2 & 1 \\
\hline & Soi Sawan & 3 & 5 & 1 & 2 & 1 \\
\hline \multirow{3}{*}{$\begin{array}{l}\text { Permian } \\
\text { Limestone }\end{array}$} & Kor Luang & 2 & 5 & 1 & 2 & 1 \\
\hline & Erawan & 2 & 5 & 1 & 3 & 5 \\
\hline & Tharn Pliew & 2 & 5 & 2 & 4 & 1 \\
\hline
\end{tabular}
score: $5=$ very good, $4=$ good,

$3=$ fair, $2=$ poor, $1=$ very poor, $0=$ none

National parks always support educational activities and create scientific panels in order to educate people. However, the majority of investigated waterfalls have poor science visibility. Almost all sites lack cultural value because local people cannot portray their cultures in national parks since they must follow/respect national laws. However, Huai Kaew has high cultural value and is located close to a Hmong village as well as Kruba Sri Wichai (Thai Buddhist monk) Monument. The economy in these sites is managed by national park authorities, excluding Wachirathan, Khlong Lan, Huai Kaew, and Erawan. Local people also collaborate in various businesses such as restaurants, souvenir shops, local transportation, and local guides. Therefore, Huai Kaew, Wachirathan, and Lan Sang are the top three in terms of the highest evaluation scores within all selected waterfalls (Figure 5). These studied waterfalls have significant potential for geotourism development, similar to Tone Nga Chang (Seven-tier) waterfall in Songkhla Province, southern Thailand, which is dominated by granitic rocks (Nazaruddin, 2019).

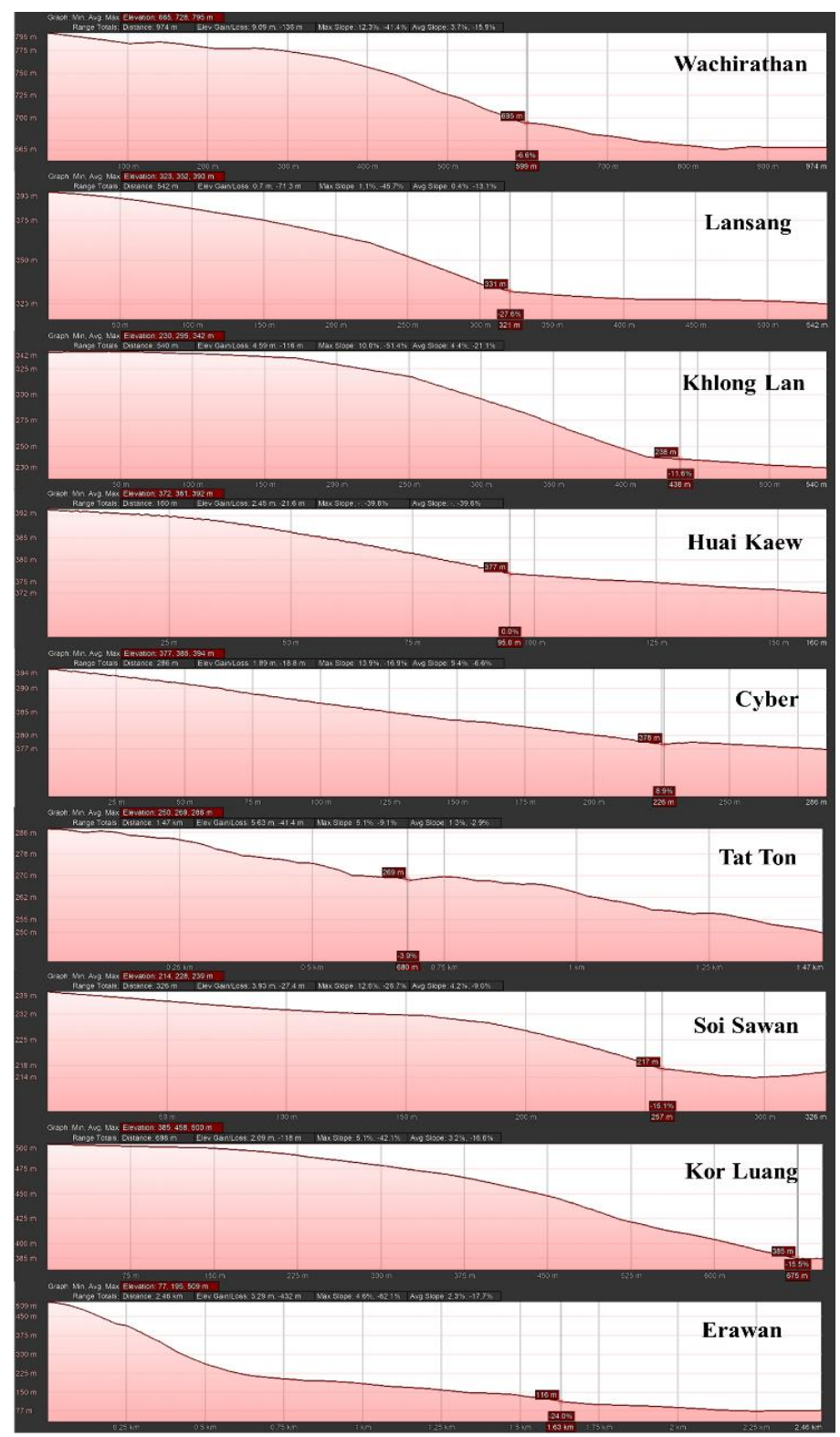

Figure 4. Elevation profile of selected waterfalls (data analyzed by Google Earth Pro 7.3.3.7786 with NVIDIA Graphics Driver (00027.00020.00 100.08681). The highlighted points present the tourist center of each area

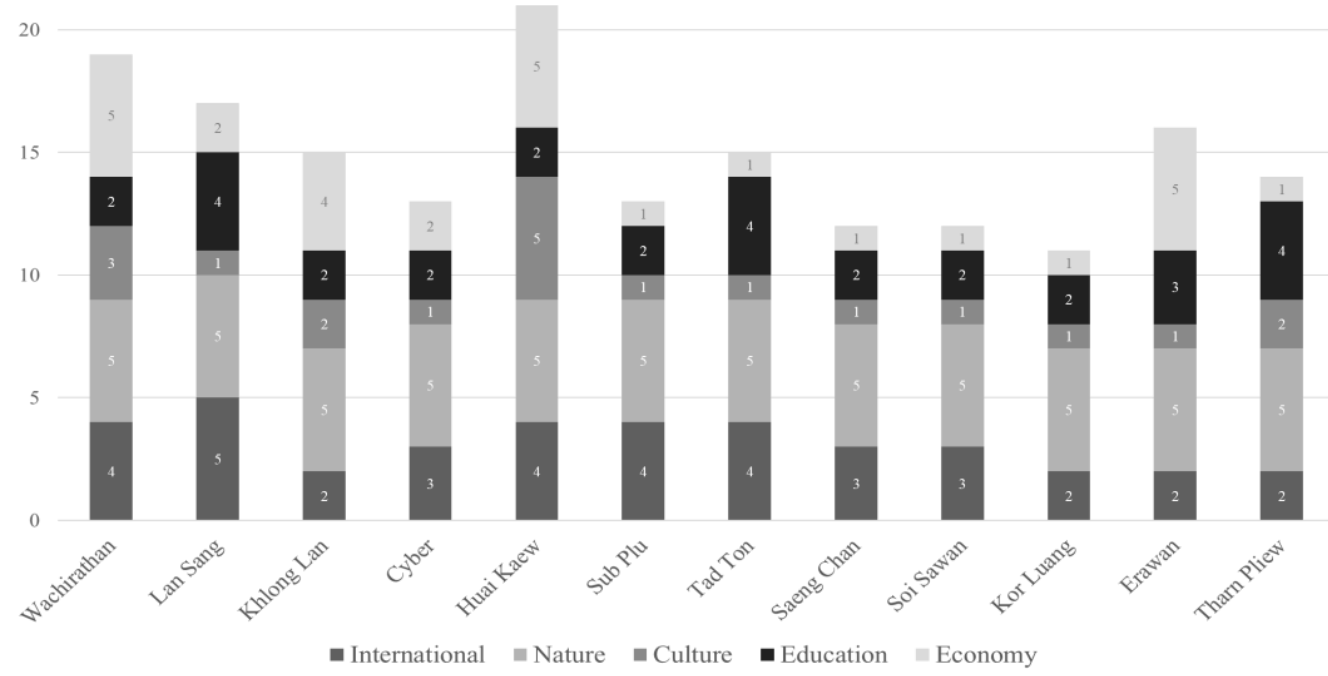

Figure 5. Quantitative geotourism assessment of studied waterfalls by field investigation and previous studied of Singtuen and Won-In (2018a, 2018b, 2018c, 2019) 


\section{CONCLUSION}

Waterfalls are common. At the same time, they are unique landforms in Thailand due to the geological settings and large number of rocks. Igneous and metamorphic waterfalls are located in Precambrian high-grade metamorphic rocks and Triassic granitoid, distributed in the northern and western parts of Thailand, specifically Chiang Mai, Tak, Kamphaeng Phet, and Uthai Thani provinces. In addition, limestone waterfalls, both Ordovician and Permian, are formed in many places, e.g. Lamphun, Kanchanaburi, and Satun. On the other hand, sandstone waterfalls are vital landforms in the Khorat Plateau, such as those in Chaiyaphum and Ubon Ratchathani provinces. Fan-type waterfalls generally present igneous and metamorphic fault-controlled basements. Meanwhile, a multi-tiered waterfall is a type formed in the limestone basement. Both types demonstrate the steep slope of waterfalls (10-13.9\% max. slope in igneous and metamorphics and 4.6-5.1\% in limestone), so there are beautiful and unique geological phenomena in these areas. Clastic sedimentary rocks with different properties in each layer always form a cascade (5.1\% max. slope with longdistance horizontal streamflow). However, Saeng Chan Waterfall is classified as a punchbowl, while Soi Sawan is a plunge type (12.6\% max. slope in escarpment) based on their characteristics and processes.

These waterfalls have high natural and tourism value, but some areas score low in terms of culture and economy that should be augmented to enhance the population's understanding of the fundamental geological processes and help reinforce the importance of their resources through sustainable geotourism development. Moreover, the international and educational values range from fair to good and could be developed further. National parks in Thailand are stimulating and support scientific as well as tourism activities and research geared toward achieving geo-sustainable development in line with the 12th National Economic and Social Development Plan (2017-2021).

\section{Acknowledgement}

The authors would like to thanks the Research Administration Division (RAD) of Khon Kean University and the Research Affairs, Faculty of Technology, Khon Kaen University, for financial support in publication. Thanks also extended to anonymous referees for their valuable comments and advice.

\section{REFERENCES}

Bait, J., Wong, I., Prachaub, S., Wechbunthung, B., Hinthong, C., \& Sarapirome, S. (1997). Contemporary seismicity in northern Thailand and its tectonic implication. In Phisit. Dheeradilok (Ed.), Proceedings of] International Conference on Stratigraphy and Tectonic Evolution of Southeast Asia and the South Pacific, 453-464, Thailand, Department of Mineral Resources.

Baum, F., Braun, E.V., Hess, A., \& Kock, K.E. (1981). Geologic map of northern Thailand, Department of Mineral Resources Thailand, Bangkok, Thailand.

Beckinsale, R.D. (1981). Granite magmatism in the tin belt of Southeast Asia, Shiva Publishing, Chandigarh, India.

Beckinsale, R.D., Suensilpong, S., Nakapadungrat, S., \& Walsh, J.N. (1979). Geochronology and geochemistry of granite magmatism in Thailand in relation to a plate tectonic model. Journal of the Geological Society, 136, 529-540. https://doi.org/10.1144/gsjgs.136.5.0529

Bunopas, S. (1981). Paleogeographic history of western Thailand and adjacent parts of Southeast Asia-a plate tectonics interpretation, Doctoral Dissertation, Victoria University of Wellington, New Zealand, 810.

Carreck, R. (1982). The Family Encyclopedia of Natural History. The Hamlyn Publishing Group, 246-248, The Hamlyn Publishing Group, London.

Đurović, P., \& Đurović, M. (2010). Inventory of geoheritage sites - the base of geotourism development in Montenegro. Geographica PannonicaGeographica Pannonica, 14(4), 126-132. https://doi.org/10.5937/GeoPan1004126D

Fenton, C., Charusiri, P., Hinthong, C., Lumjuan, A., \& Mangkornkarn, B. (1997). Late Quaternary faulting in northern Thailand. In Phisit. Dheeradilok (Ed.), Proceedings of the International Conference on Stratigraphy and Tectonic Evolution of Southeast Asia and the South Pacific, 436-452, Bangkok: Department of Mineral Resources Thailand.

Goudie, A.S., (2020). Waterfalls: forms, distribution, processes and rates of recession. Quaestiones Geographicae, 39(1), 59-77. https://doi.org/10.2478/quageo-2020-0005

Hutchison, C.S. (1983). Multiple Mesozoic Sn-W-Sb granitoids of Southeast Asia. Geological Society of America Memoirs, $159,35-60$.

Kosuwan, S., Charusiri, P., Takashima I., \& Lumjuan, A. (1998). Active tectonics of the Mae Chan Fault, northern Thailand. In Guan Hoe. Teh (Ed.), Proceedings of Ninth Regional Conference on Geology, Mineral and Energy Resources of Southeast Asia, 653-665, Kuala Lumpur: Geological Society of Malaysia.

Limtrakun, P., Panjasawatwong, Y., \& Khanmanee, J. (2013). Petrochemistry and origin of basalt breccia from Ban Sap Sawat area, Wichian Buri, Phetchabun, central Thailand. Songklanakarin Journal of Science and Technology, 35(4), 469-482.

Mabin, M.C.G. (2000). In search of Australia's highest waterfalls. Australian Geographical Studies, 38(1), 85-90.

Macdonald, A.S., Barr, S.M., Miller, B.V., Reynolds, P.H., Rhodes, B.P., \& Yokart, B. (2010). P-T-t constraints on the development of the Doi Inthanon metamorphic core complex domain and implications for the evolution of the western gneiss belt, northern Thailand. Journal of Asian Earth Sciences, 37, 82-104. https://doi.org/10.1016/j.jseaes.2009.07.010

Matthes, F.E. (1922). Which is the highest water fall in the World?. Science, 56(1438), 75-76.

Meesook, A. (2000). Cretaceous environment of northeastern Thailand. In Cretaceous environment of Asia, 207-223, Elsevier Science Publishers BV, Amsterdam.

Metcalfe, I. (2011). Tectonic framework and Phanerozoic evolution of Sundaland. Gondwana Research, 19(1), 3-21. https://doi.org/10.1016/j.gr.2010.02.016

Metcalfe, I. (2013). Gondwana dispersion and Asian accretion: tectonic and palaeogeographic evolution of eastern Tethys. Journal of Asian Earth Sciences, 66(8), 1-33. https://doi.org/10.1016/j.jseaes.2012.12.020

Morley, C.K. (2009a). Evolution from an oblique subduction back-arc mobile belt to a highly oblique collisional margin: the Cenozoic tectonic development of Thailand and eastern Myanmar. Journal of the Geological Society, 318, 373-403. https://doi.org/10.1144/SP318.1

Morley, C.K. (2009b). Geometry and evolution of low-angle normal faults (LANF) within a Cenozoic high-angle rift system, Thailand: implications 
for sedimentology and the mechanisms of LANF development. Tectonics, 28(5, TC5001. https://doi.org/10.1029/2007TC002202

Nazaruddin, D.A. (2015). Systematic Studies of Geoheritage in Jeli District, Kelantan, Malaysia. Geoheritage, 9(1), 19-33. https://doi.org/10.1007/s12371-015-0173-9

Nazaruddin, D.A. (2019). Selected Geosites for Geoheritage, Geotourism, and Geoconservation in Songkhla Province, Southern Thailand. Quaestiones Geographicae, 38(1), 161-177. https://doi.org/10.2478/quageo-2019-0011

Österle, J.E., Klötzli, U., Stockli, D.F., Palzer-Khomenko, M., \& Kanjanapayont, P. (2019). New age constraints on the Lan Sang gneiss complex, Thailand, and the timing of activity of the Mae Ping shear zone from in-situ and depth-profile zircon and monazite U-Th$\mathrm{Pb}$ geochronology. Journal of Asian Earth Sciences, 181, 1367-9120. https://doi.org/10.1016/j.jseaes.2019.103886

Palin, R.M., Searle, M.P., Morley, C.K., Charusiri, P., Horstwood, M.S.A., \& Roberts, N.M.W. (2013). Timing of metamorphism of the Lansang gneiss and implications for left-lateral motion along the Mae Ping (Wang Chao) strike-slip fault, Thailand. Journal of Asian Earth Sciences, 76, 120-136. https://doi.org/10.1016/j.jseaes.2013.01.021

Pasternack, G.B., Ellis, C., Leier, K.A., Valle, B.L., \& Marr, J.D. (2006). Convergent hydraulics at horseshoe steps in bedrock rivers. Geomorphology, 82:126-145. https://doi.org/10.1016/j.geomorph.2005.08.022

Pasternack, G.B., Ellis, C.R., \& Marr, J.D. (2007). Jet and hydraulic jump near-bed stresses below a horseshoe waterfall. Water Resources Research, 43, W07449. https://doi.org/10.1029/2006WR005774

Plumb, G.A. (1993). A scale for comparing the visual magnitude of waterfalls. Earth-Science Review, 34(4), 261-270.

Pralong, J.P. (2005). A method for assessing tourist potential and use of geomorphological sites. Geomorphologie: relief, processus, environnement, 11(3), 189-196. https://doi.org/10.4000/geomorphologie.350

Singtuen, V., \& Won-In, K. (2018a). Geoheritage Sites and Geoconservation at Pha Chan - Sam Phan Bok Geopark, Ubon Ratchathani Province, Thailand. Geoconservation Research, 2(1), 12-25. https://doi.org/10.30486/GCR.2019.664490

Singtuen, V., \& Won-In, K. (2018b). Geodiversity and Geoconservation of the Chaiyaphum Region in Thailand for Sustainable Geotourism Planning. GeoJournal of Tourism and Geosite, 22(2), 548-560. https://doi.org/10.30892/gtg.22223-310

Singtuen, V., \& Won-In, K. (2018c). Geological Perspective for Geotourism Development in Uthai Thani Province, Thailand. Journal of Environmental Management and Tourism, 9(5), 1003-1010. https://doi.org/10.14505//jemt.9.5(29).12

Singtuen, V., Gałka, E., Phajuy, B., \& Won-In, K. (2019). Evaluation and Geopark Perspective of the Geoheritage Resources in Chiang Mai Area, Northern Thailand. Geoheritage, 11, 1955-1972. https://doi.org/10.1007/s12371-019-00410-0

Sone, M., \& Metcalfe, I. (2008). Parallel tethyan sutures in mainland SE Asia: new insights for palaeo-Tethys closure. Comptes Rendus Geosciences, 340(2), 166-179. https://doi.org/10.1016/j.crte.2007.09.008

Sone, M., Metcalfe, I., \& Chaodumrong, P. (2012). The Chanthaburi terrane of southeastern Thailand: stratigraphic confirmation as a disrupted segment of the Sukhothai arc. Journal of Asian Earth Sciences, 61, 16-32. https://doi.org/10.1016/j.jseaes.2012.08.021

Sriwichai, M., Rachanark, B., Assavapanuva, Pr., Wattanachareekul, P., Makakum, Ch., Watcharamai, Th., Ardkham, P., Chaikam, A., Phujareanchaiwon, Ch., Srisunthon, Pr., Leknettip, S., Kaewpaluk, S., Khamsir, S., \& Chawchai, S. (2018). Preliminary study of basaltic rock in Phetchabun, Thailand. Bulletin of Earth Sciences of Thailand, 9(1), 44-54.

Ueno, K., \& Hisada, K. (2001). The Nan-Uttaradit-Sa Kaeo suture as a main paleo-Tethyan suture in Thailand: is it real?. Gondwana Research, 4(4), 804-806. https://doi.org/10.1016/S1342-937X(05)70590-6

*** DMR. (1999). Geologic map of northern Thailand, Department of Mineral Resources Thailand, Bangkok, Thailand.

*** National Geographic, (2018). Waterfall. Online: www.nationalgeographic.org/encyclopedia/waterfall (accessed 20 December 2018).

Article history: Received: 05.05.2021 Revised: 19.07.2021 Accepted: 27.08.2021 Available online: 17.09.2021 